\title{
A study of physical and chemical properties of internal accumulated material in water mains
}

\author{
상수관로 내부 오염물질의 물리화학적 특성 분석
}

\author{
Bae, Cheol-Ho' $\cdot$ Choi Doo-Yong ${ }^{1} \cdot$ Lee, Doo-Jin $^{1^{*}} \cdot \mathrm{Kim}$, Do-Hwan ${ }^{2}$ \\ 배철호 ${ }^{1} \cdot$ 최두용 ${ }^{1} \cdot$ 이두진 ${ }^{*} \cdot$ 김도환 ${ }^{2}$
}

'Water and Wastewater Research Center, K-water Research Institute, Korea Water Resources Corporation - Water Quality Institute, Busan Water Authority

${ }^{1} \mathrm{~K}$-water연구원 상하수도연구소 · ${ }^{2}$ 부산광역시 상수도사업본부 수질연구소

\begin{abstract}
Tuberculation and slime accumulated in water mains play an important role in modifying water quality of drinking water. Therefore, in this study, it was investigated that what materials were accumulated, and what components were included in the tuberculation and slime of water mains. The Various tuberculation and slime sample were collected from the 12 water mains to analyze their physical and chemical properties and crystal structure. As a analysis method, VSS(Volatile suspended solid), SEM(scanning electron microscope), EDS(Energy Dispersive X-ray spectroscope), ICP(Inductively Coupled Plasma Mass Spectrometer) and XRD(X-Ray Diffractomete) were used. The results of analysis on the samples, the representative materials were verified such as iron corrosion products, the fine sand particles generated during backwash, fine particles of activated carbon, aluminum used in coagulation process, and manganese included in raw water.
\end{abstract}

Key words : Water mains, pollution, slime, tuberculation, EDS, XRD

주제어 : 상수관로, 관로오염, 슬라임, 결절, $\mathrm{EDS}, \mathrm{XRD}$

\section{1. 서 론}

상수관망에서 내부에 존재하는 오염물질은 보 편적으로 부식생성물, 실트, 모래, 생물막, 화학 적 스케일, 유·무기 미립자, 그리고 관내부 도장 재 등을 포함하고 있다. Walski(1991)에 따르면, 이러한 오염물질들은 잔류 소독제를 감소시키고 독성 또는 병원성 박테리아 등의 생장에 영향을 주기 때문에 공공보건을 위협한다고 하였다. 또한 적수 등은 탁도 및 색도변화(discoloration)의 주 요원인이기도 하다.

따라서 현재 많은 연구자들이 상수관로 내부에

- Received 03 September 2014, revised 13 October 2014, accepted 15 October 2014.

* Corresponding author: Tel : 042-870-7320 E-mail : djlee@kwater.or.kr
존재하는 다양한 오염물질에 대한 연구를 활발히 진행하여 왔으며, 이러한 연구는 크게 슬라임과 같은 관 표면에 부착 또는 축적된 침전물, 미생물 막 등의 분포를 조사하는 분야와 관재질의 변형( 부식, 도장재 탈리 등) 및 열화 등을 분석하는 분 야로 구분할 수 있다.

관련연구 동향을 살펴보면, 초기에는 관내 침 전물에 대한 성분과 결정구조를 규명하는데 주로 초점이 맞추어 졌다. Kolle and Rosch(1980) 등 은 상수관로 내부의 금속 바닥층은 부식이 진행되 어 녹과 기타 생성물층으로 덮여있다고 설명하였 다. 이 층은 본래의 철 물질과 흑연의 혼합물을 포 함(topotactic layer)하고 있으며, 이 층 위에는 내부부식에 의한 결절을 형성하는 철 산화물이 축 
적(epitactic layer)되어 있다. 결절의 경계는 조 개껍질과 유사한(shell-like) 층이 존재하는 것 으로 보고되고 있으며, 이 조개껍질 층은 다공성 의 부착력이 약한 침전물로 geothite(침철석)와 calcite(방해석)로 구성되어 있는 것으로 알려져 있다. Smith et al. (1997)은 영국의 남동쪽에 위 치한 Thames water의 상수관망에 대한 부식생 성물의 화학적 조성을 연구한 결과, 관 벽 침전 물은 매우 유사한 조성을 가지고 있는 것으로 나 타났다. 침전물은 주로 산화철 혼합물(magnetite), iron oxyhydroxides(Gepthite와 Lepidocrocite), 그리고 철과 탄산칼슘(siderite(능 철광)와 calcite) 등의 무기질 광물로 구성되어 있었다. Clemant et al. (1998)은 미국의 여러 도시에서 관체를 수집해서 스케일과 미생물 막에 대해서 조사하였다. 관재질은 주철, 납, 그리고 아연도강관 등이었고, SEM(scanning electro microscopy), EDS(Energy dispersive spectroscopy), $\mathrm{XRD}(\mathrm{x}$-ray diffrcation) 등을 분 석하였다. 주철관종에서 주요 원소성분으로 관 측된 것은 철, 칼슘, 규소, 그리고 황 등이었다. 납 관종에서 관측된 주요 원소성분은 납, 알루 미늄, 그리고 규소 등이었다. 아연도강관은 철, 알루미늄, 그리고 규소 등이었다. Geothite 등 은 모든 주철관종과 하나의 아연도강관에 관측 이 되었고, magnetite는 거의 모든 관종에서 나타났다. 하이드로진사이트(Hydrocerussite, $\left.\mathrm{Pb}_{3}\left(\mathrm{CO}_{3}\right)_{2}(\mathrm{OH})_{2}\right)$ 는 납 관종에서만 나타났다.

상수관망에서 미생물 막의 형성에 대한 메커 니즘은 수도사업자에게는 매우 중요한 관심사 이다. 이는 미생물학적인 스케일이 수인성 질병 을 유발할 잠재적 위험성을 가지고 있기 때문이 다. 또한 생물막의 형성은 상수관로의 부식을 가 속화할 수 있고, 심미적인 수질문제를 유발하기 도 한다. Nagy and Olson(1985)은 다양한 종 류의 관 표면에서 $\mathrm{HPC}$ 밀도가 $100 \mathrm{~cm}^{2}$ 당 10 bacteria와 $100 \mathrm{~cm}^{2}$ 당 $4.7 \times 10^{6}$ bacteria 사이 로 보고하였다. 그들은 관 표면에 주로 Arthrobactor가 존재하고, 생물막내에 Flavobacte- rium, Moraaxella, Acinetobactor, Bacillus, Pseudomons, Alcaligenes, 그리고 Achromobactor 등이 존재하는 것으로 보고하였다. 그들은 관 표면의 박테리아 밀도와 매설년수에 대한 상관성을 분석하였는데, 매 일년마다 10 배 씩 박테리아가 증가하는 것으로 평가하였다. 일 부 연구자들이 부식생성물인 결절 내에 대장균이 존재함을 보여주었다. LeChevallier 등(1987) 은 Escherichia coli(fecal coliform positive), C. freundii, 그리고 E. agglomerans 등을 역 청계로 코팅된 시멘트모르터 라이닝 주철관종에 서 확인하였다. Emde et al.(1992)은 총 대장균 이 정수되지 않은 물에서 보다 부식침전물 속에 오히려 상당량 존재함을 확인하였다.

국내에서도 일부 관내부 세척 후 발생되는 방 류수 또는 침전고형물에 대하여 제한적으로 분 석한 바 있으나, 체계적인 조사 연구가 진행된 바는 거의 없는 실정이다.

사실 이러한 연구는 단순히 관내 오염물질이 무엇인가를 규명하는데 치중한 측면도 있으나, 이들 오염물질의 정보와 발생기전에 대한 이해 를 통하여 상수관망 수질안전성 확보를 위한 대 안을 찾는데 도움을 얻을 수 있다. 즉 원수 자 체가 발생원인지, 그래서 정수처리공정을 더 강 화하여야 하는지, 아니면 정수처리공정 또는 관 로 자체에서 발생이 되고 있는지 알아야 정수처 리공정을 개선할지 또는 관로 자체에 대해서도 어떤 방법으로 오염물질을 제거하고 제어할지에 대한 명확한 치료책 마련이 가능하다.

따라서 본 연구에서는 국내 상수관로 내 존재 하는 다양한 슬라임 등 축적물질과 부식으로 인 해 관 내부에 형성된 결절 등에 대한 물리화학적 인 특성을 분석하여, 이러한 물질의 발생원인이 무엇인지 파악하였다. 또한 상수관로는 그 용도 에 따라 원수, 공업용수, 정수 등을 공급하고 있 고, 관종 또한 매우 다양한 특성을 보이기 때문 에 관 내부에 존재하는 오염물질의 형태도 매우 다를 수 있으므로 관 용도와 관종 별로 관 내부에 존재하는 오염물질의 성분을 규명하고자 하였다. 


\section{2. 연구방법}

\section{1 조사대상관로}

본 연구에서는 도수관로, 배수관로, 그리고 공업용수관로 등으로 상수관로 용도별로 구분하 여 원수, 침전수, 그리고 정수 등에 대한 영향, 그리고 관 재질에 따라 내부에 존재하는 다양한 슬라임과 결절 등에 대한 물리화학적 특성 분석 을 위해 무라이닝 주철관종(회주철, 닥타일주철 관), 시멘트모르터라이닝 닥타일주철관, 강관, $\mathrm{PE}$ 관, 콘크리트관에 대해 조사하였다.

본 연구에서 조사한 대상관로에 대한 용도, 재 질, 그리고 분석대상 샘플에 대한 정보는 Table
1 과 같다.

\section{2 샘플수집 방법}

조사대상 관로내부에 존재하는 슬라임 또는 결절에 대한 샘플링은 해당관로에 대해 길이방 향으로 $1 \sim 2 \mathrm{~m}$ 이상을 절단하여 수집하거나 또는 대구경으로 수집이 어려운 경우에는 관 절 단 후 관 내부 부착물질을 직접 채취 하였다. 결 절에 대해서는 결절표면은 대부분 빨간 색의 옅 은 슬라임이 존재하나, 내부 층으로 갈수록 검은 색의 산화철 계통의 물질로 변화되는 특성을 보 이기 때문에 결절상부는 surface layer, 중간부 위는 middle layer, 하층부는 bottom layer 로

Table 1. Statues of water mains investigated

\begin{tabular}{|c|c|c|c|c|c|}
\hline Area & Use & Materials & Diameter & Installation year & Sample \\
\hline \hline CW & Raw water & Unlined CIP & 600 & 1967 & tuberculation \\
\hline \multirow{2}{*}{ US } & Industrial water & Unlined DIP & 1200 & 1968 & tuberculation \\
\cline { 3 - 6 } & IS & Concrete & 1200 & 1968 & Slime \\
\hline JD & Drinking water & $\begin{array}{c}\text { Steel pipe } \\
\text { (coal-tar enamel lined) }\end{array}$ & 1100 & 1982 & Slime \\
\hline TY & Drinking water & Unlined DIP & 100 & $<1980$ & tuberculation \\
\hline KK & Drinking water & Unlined DIP & 100 & $<1980$ & tuberculation DIP \\
\hline GS & Drinking water & Polyethylene pipe & 100 & $<1980$ & tuberculation \\
\hline GJ & Drinking water & $\begin{array}{c}\text { Steel pipe } \\
\text { (Epoxy resin lined) }\end{array}$ & 200 & 1998 & Slime \\
\hline KJ & Drinking water & Cement mortar lining DIP & 200 & 1984 & tuberculation \\
\hline DD & Drinking water & $\begin{array}{c}\text { Steel pipe } \\
\text { (coal-tar enamel lined) }\end{array}$ & 700 & 1986 & Slime \\
\hline
\end{tabular}

\begin{tabular}{|c|c|c|c|c|c|}
\hline & Tuberculation & & & \\
\hline & & & & \\
\hline
\end{tabular}

Fig. 1. Pictures of collected sample. 
구분하여 샘플링을 하여 각 층별로 물리화학적 특성변화를 분석하였다. 슬라임에 대해서는 대 구경은 현장에서 관 표면에 축적되어 있는 슬라 임을 표면으로부터 긁어내어 샘플링을 하였고, 소구경은 수집된 관체 내부에 증류수를 흘리면 서 브러싱(brushing)하여 수집하였다. 조사대 상 관로로부터 수집한 샘플에 대한 상태는 Fig. 1 과 같다.

\section{3 분석방법}

본 연구에서는 상수관로 내부에 존재하는 다 양한 슬라임과 결절에 대한 성분, 조직, 결정구 조, 화학적 원소 등을 분석하였고 그 방법은 다 음과 같다.

(1) 휘발성 부유고형물(Volatile suspended solid, VSS)

수집한 모든 샘플에는 관 내부 표면에 물과 접 촉으로 수분을 포함하고 있다. 따라서 수집한 샘 플에 대해서 $105^{\circ} \mathrm{C}$ 에서 2 시간 이상 건조 후 무 게를 측정하고, 다시 $550^{\circ} \mathrm{C}$ 에서 20 분간 강열 후 무게를 측정하여 산정하였다.

(2) 미세조직과 형상분석

수집한 모든 샘플에 대한 미세 조직과 형 상을 관찰하기 위해 $\mathrm{SEM}$ 촬영을 하였다. $\mathrm{SEM}(\mathrm{JEOL}, \mathrm{JSM}-7000 \mathrm{~F})$ 은 전자총 부분의 Filament에 전원을 가하여 방출된 전자를 높은 전압으로 가속하여 $(10-30 \mathrm{kV})$ 집속렌즈로 모아 서 시료 표면에 조사시켜 시료에서 방출되는 여 러 가지 신호 중 2차 전자를 검출하여 영상화함 으로서 시료에 대한 미세조직과 형상을 파악하 는데 도움을 준다.

(3) 화학적 원소성분 분석

본 연구에서는 수집한 모든 샘플에 대해 $\mathrm{EDS}$ 를 분석하여 시료 내 원소(element)에 대한 정 성 · 정량적 분석을 수행하였다. 사용된 장비는 JXA 8800R(JEOL Japan LTD)이며, 전자총 으로 부터 일차 전자가 도달된 시편의 표면에서 발생하는 특성 $X$-선을 검출하여 시료내 원소들
에 대한 정성과 정량(Point, Line, Mapping) 이 가능하다.

(4) 중금속의 화학적 조성분석

수집한 모든 샘플에 대한 화학적 조성은 ICP(Inductively Coupled Plasma, Perkin Elmer, OPTIMA 7300DV, USA)를 이용하였 다. 분석항목으로는 관 내부 결절 또는 슬라임 등의 주요 성분으로 알려진 $\mathrm{Fe}, \mathrm{Al}, \mathrm{Mn}, \mathrm{Zn}$, $\mathrm{Ca}, \mathrm{Cu}$ 등에 국한하여 정량적 분석을 수행하 였다.

(5) 광물학적 결정구조

수집한 모든 샘플에 대한 결정구조에 대한 정 성 - 정량적 분석은 고 분해능 $\mathrm{X}$-선 회절분석 기(Bruker AXS, Germany)를 이용하여 관 내 부에 존재하는 결절과 축적물질의 결정구조에 대한 정성 - 정량적 분석을 수행하였다. Bruker AXS는 D8 Advance model로써 Lynxeye detector(linear detector or PSA)가 장착되 어 있으며, $\mathrm{X}$-ray tube의 Target은 $\mathrm{Cu}$ 이며 Nickel filter를 사용하였고 $40 \mathrm{kV}, 40 \mathrm{~mA}$ 로 분석하였다.

각 샘플에 대한 측정방법과 분석내용은 이를 Table 2에 요약하여 나타내었다.

Table 2. Analysis method of slime and tuberculation

\begin{tabular}{|c|c|l|}
\hline Analysis method & contents & \multicolumn{1}{|c|}{ object } \\
\hline \hline Drying method & $\begin{array}{c}\text { amount of volatile } \\
\text { suspended solid }\end{array}$ & $\begin{array}{l}\text { - tuberculation } \\
\text { - slime }\end{array}$ \\
\hline $\begin{array}{c}\text { scanning electron } \\
\text { microscope(SEM) }\end{array}$ & $\begin{array}{c}\text { Microstructure and } \\
\text { morphology }\end{array}$ & - tuberculation \\
\hline $\begin{array}{c}\text { Energy Dispersive } \\
\text { X-ray spectroscope } \\
\text { (EDS) }\end{array}$ & $\begin{array}{c}\text { Chemical } \\
\text { composition(Wt, \%) } \\
\text { of atomic elements }\end{array}$ & $\begin{array}{l}\text { - tuberculation } \\
\text { - slime }\end{array}$ \\
\hline $\begin{array}{c}\text { Inductively } \\
\text { Coupled Plasma Mass } \\
\text { Spectrometer(ICP) }\end{array}$ & $\begin{array}{c}\text { Quantity of } \\
\text { Inorganic substance }\end{array}$ & - tuberculation \\
\hline $\begin{array}{c}\text { X-Ray } \\
\text { Diffractometer(XRD) }\end{array}$ & $\begin{array}{c}\text { Verification of } \\
\text { crystal structure }\end{array}$ & - tuberculation \\
\hline
\end{tabular}




\section{3. 연구결과}

\subsection{SEM 측정결과}

Fig. 2에는 수집한 결절에 대한 $\mathrm{SEM}$ 측정 결과를 나타내었다. Fig. 2에서 SEM 측정결과 를 보면, 배율에 따라 보이는 상태는 다르나, 침 상 또는 원형 등 다양한 형태로 존재하고 있는 것으로 보이며, 결절들은 연속적인 조직을 구 성하기 보다는 전체적으로 매우 많은 Pore 등 이 내부에 존재하는 것으로 판단된다. Sarin et al. (2001)이 Boston에서 수집한 주철관종 내 결 절의 porosity는 $39.56 \sim 54.33 \%$ 범위로 보고 한바 있다. Fig. 2(a)에 나타난 조직은 Borch et al.(2008)이 수행한 결절에 대한 SEM 측정 결과에서 보여준 유사한 구조로, 이러한 결정구 조를 geothite 또는 megnetite로 추정한 바 있 다. 또한 Fig. 2(b)의 육각형과 유사한 구조들 은 침상구조를 갖는 geothite에서 나타나는 구 조로 보았다. Borch et al.(2008)은 SEM 측정

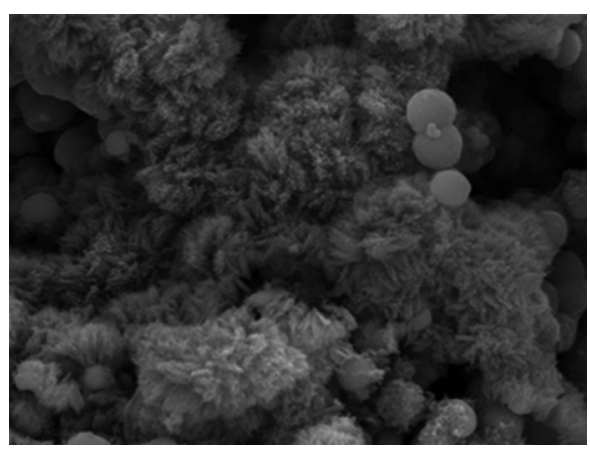

(a) $\mathrm{KK}(\times 2,000)$

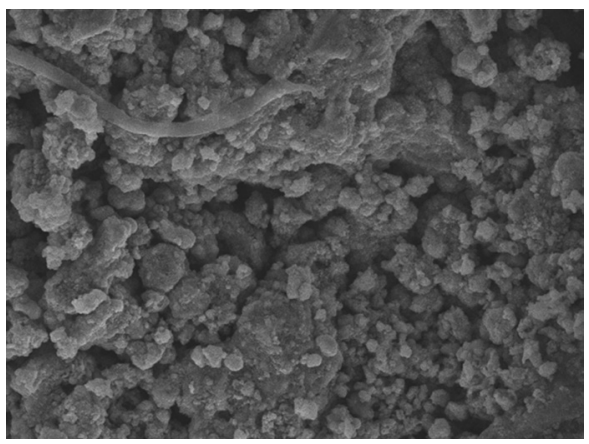

(c) JD $(\times 2,000)$

Fig. 2. Results of SEM analysis on collected tuberculation.
을 통하여 결절 내에서 원형구조를 갖는 밀집조 직도 발견하였는데, 이러한 구조는 megnetite 로 추정하였다.

Borch et al.(2008)은 결절 속에서 구균형 태(Cocci-shaped)의 bacteria도 발견하여 보 고한 바 있는데, Fig. 2에서도 국내에서 수집한 결절 속에도 일부 미생물로 추정되는 형태가 발 견되었다. 다양한 미생물도 포함되어 있기 때문 에, 부분적으로 미생물 형태로 보이는 조직(선형 (Fig.2의 c)) 또는 원형(Fig.2의 (a)와 (d))도 촬 영이 되었다. 따라서 결절이라 하더라도 단순 부 식 생성물 또는 무기성분, 유기물만 구성된 것은 아니며, 다양한 입자들과 미생물 등이 혼합되어 존재하는 것으로 판단된다. Allen et al.(1980) 도 미국내 7 개 수도시설에서 결절 표면에 대해 서 SEM을 이용해서 분석한 바 있는데, 7 개 결절 의 물리적인 특성은 유사하였고 모두 단단하지 만 다공성 표면을 가지고 있는 것으로 나타났다. 또한 많은 사례에서 actinomycetes, algae, 그

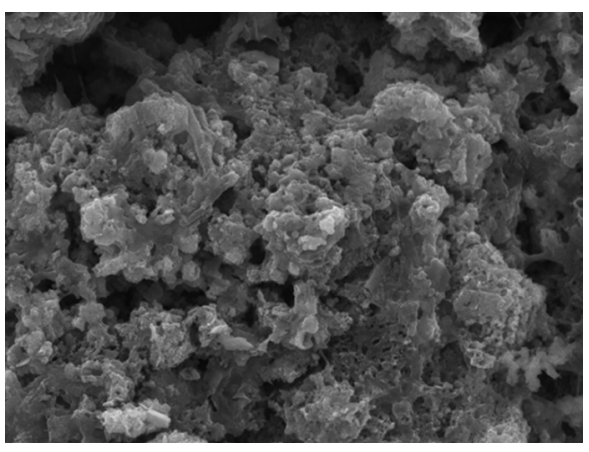

(b) GJ $(\times 3,000)$

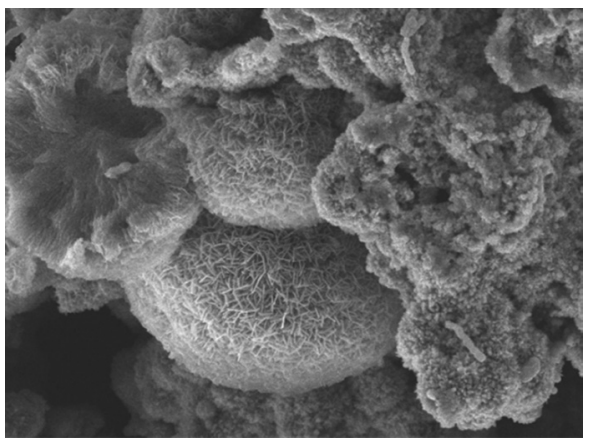

(d) JD $(\times 2,000)$ 
리고 diatoms 등과 같은 미생물들이 표면 또는 표면주변에서 발견된 바 있다.

\subsection{VSS 측정결과}

Fig. 3 에는 수집한 관체의 결절과 슬라임에 대 한 평균 $\operatorname{VSS}($ Volatile suspended solid)를 나 타내었다. VSS는 결절과 슬라임에 존재하는 휘 발성부유고형물을 나타낸다. Fig. 3에서 결절의 평균 $\mathrm{VSS}$ 는 $12.03 \%$, 슬라임은 $24.18 \%$ 로 결절 보다 슬라임 속에 포함된 VSS의 양이 2 배 정도 높았다. 그 이유는 결절은 주로 철 부식생성물로 철 성분이 대부분을 포함하고 있으나, 슬라임 등 에는 이러한 미생물 등 유기물 성분비율이 더 높 기 때문으로 판단된다. 이는 Vreeburg(2007)도 네덜란드 Amstelveensewg의 수돗물 속에 존 재하는 관내 축적 입자를 포집하여 TSS(Total suspended solid)를 분석하였는데, 이중 VSS 가 약 $15 \sim 55 \%$ (평균적으로 33\%)로 변화가 매 우 심한 것으로 나타났으며, 대부분 이들 성분이 미생물학적인 프로세스로 발생하고 그 양이 증 가하는 것으로 보고한 바 있기 때문이다.

Fig. 4에는 원수를 공급하는 무라이닝 회주 철관(Unlined-CIP), 공업용수를 공급하는 닥 타일주철관(Unlined-DIP), 그리고 정수를 공 급하는 무라이닝 닥타일주철관(Unlined-DIP) 과 강관(SP) 내 결절에 포함된 $\mathrm{VSS}$ 를 비교하여 나타내었다. Fig. 4에서 보면, 공업용수를 공급 하는 unlined-DIP의 VSS가 평균 $18.22 \%$ 으로 가장 높았고, 원수 또는 정수를 공급하는 관종 (Unlined-CIP, Unlined-DIP, SP)에서는 상 대적으로 낮은 $9.99 \sim 11.24 \%$ 로 유사한 수준을 보였다. 공업용수를 공급하는 unlined-DIP가 타 용수공급의 관 재질에 비하여 가장 높은 VSS 를 보였으며 이는 공업용수 처리공정이 응집, 침 전과정까지만 진행되므로 상대적으로 미생물 및 유기물 제거효율이 낮기 때문에 VSS의 비중이 큰 것으로 추측된다.

Fig. 5에는 원수를 공급하는 concrete관, 그
리고 정수를 공급하는 $\mathrm{SP}, \mathrm{CML}-\mathrm{DCIP}$ 내부 에 존재하는 슬라임 사이의 $\mathrm{VSS}$ 를 비교하여 나 타내었다. 슬라임 내 VSS는 정수를 공급하는 $\mathrm{SP}$ 가 $33.28 \%$ 으로 가장 높았고, 그 다음으로는 CML-DCIP가 $14.10 \%$ 이었으며, 원수를 공급하 는 concrete관이 $6.93 \%$ 로 가장 낮게 나타났다. 이러한 이유는 내부 도장재로 사용되고 있는 시 멘트모르터 또는 콘크리트 표면 자체가 폴리머 재질의 고분자 라이닝 재질에 비하여 미생물 등 프로세스의 발달에 더 취약하기 때문으로 보인 다. Clark et al.(1994)은 고분자 재질인 PVC

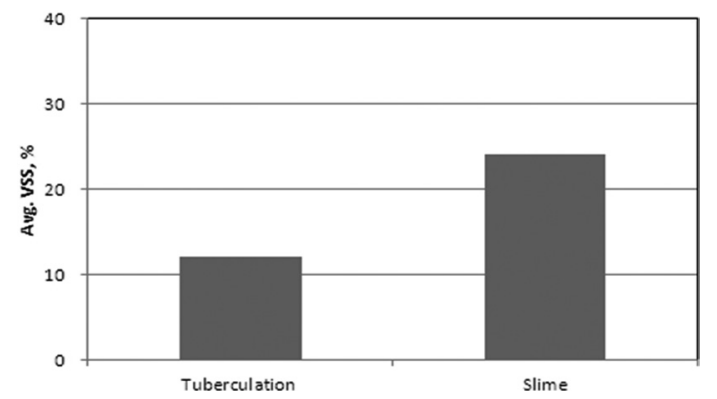

Fig. 3. Comparison of average VSS on tuberculation and slime.

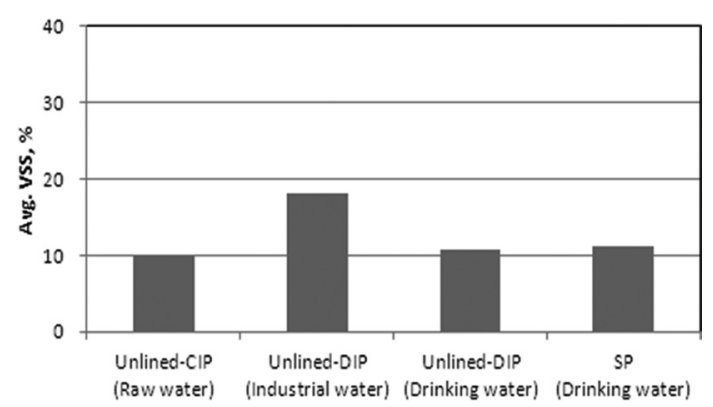

Fig. 4. Results of VSS analysis on tuberculation,

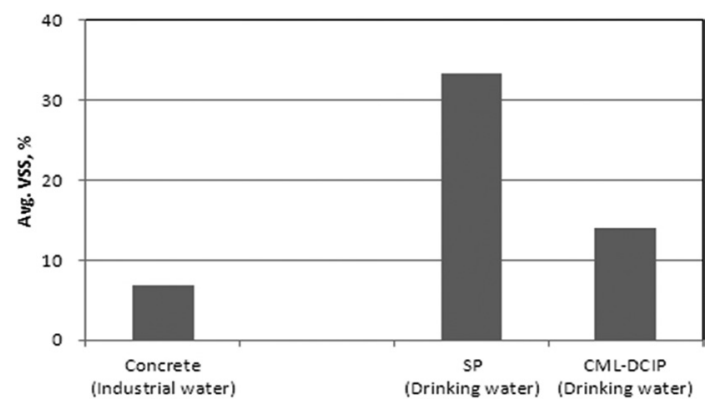

Fig. 5. Results of VSS analysis on slime. 
와 $\mathrm{PE}$ 에 비하여, $\mathrm{CML}-\mathrm{DCIP}$ 가 가장 낮은 미 생물 막 농도를 보여주었고, 최근 Hallam et al.(2001)도 PVC와 MDPE가 잠재적으로 미생 물 막의 성장에 더 좋은 것으로 보고 한바 있다. 그러나 일부 연구에서는 이와는 반대의 결과도 보고되고 있어 재질적 영향도 중요하나, 수질, 수리적 환경 또한 중요할 것으로 판단된다.

\subsection{EDS 분석 결과}

Fig. 6 에는 수집한 관체에 대한 결절과 슬라 임에 대한 $\mathrm{EDS}$ 분석결과를 질량 조성비 $(\mathrm{wt}, \%)$ 로 나타내었다. Fig. 6에서 보면, 결절과 슬라임 에 가장 많은 비중을 차지하고 있는 성분은 철 성 분이며, 그 다음으로는 철 이외의 성분과 산화물 또는 화합물로 존재하는 산소 또는 탄소 성분 등 의 유기물을 구성하고 있는 성분으로 보여 진다. 이는 결절 또는 슬라임에는 평균적으로 $10 \sim 20$ $\%$ 의 VSS가 존재하고 있기 때문이다. 그 외 비중 이 높은 성분은 알루미늄 $(\mathrm{Al})$, 규소 $(\mathrm{Si})$, 그리고 망간 $(\mathrm{Mn})$ 성분이며, $\mathrm{Mg}, \mathrm{S}, \mathrm{Cl}, \mathrm{K}, \mathrm{Ca}$ 등이 존 재하는 것으로 나타났다. 그 외 결절에는 관체에 따라 극미량의 $\mathrm{Na}, \mathrm{P}, \mathrm{Ti}, \mathrm{Ni}, \mathrm{Cu}$ 등이 분석되 었으며, 슬라임에는 $\mathrm{F}, \mathrm{Na}, \mathrm{P}, \mathrm{Zn}$ 등도 존재하 였다(극미량 $0.5 \%$ 이하로 Fig. 6에는 미포함).

따라서 전체적으로 관로 내부에 존재하는 결 절과 슬라임의 주요성분은 철, 알루미늄, 규소, 망간 등이 주요성분으로 볼 수 있다. 이중 철은

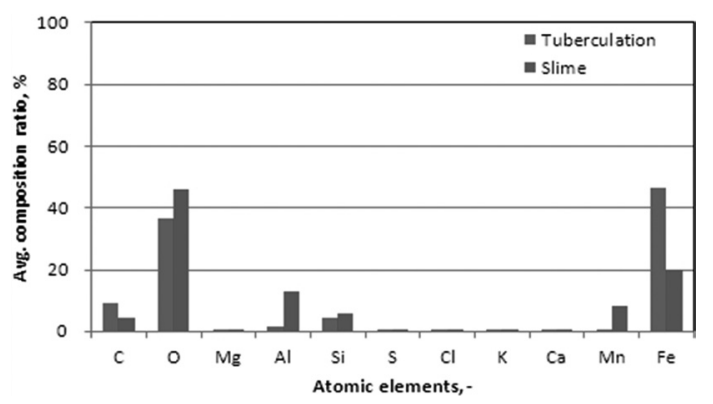

Fig. 6. Chemical composition comparison of atomic elements on tuberculation and slime.
원수 속에 포함된 성분일 수도 있으나, 그 비중 이 높은 것으로 보아 주철관종 또는 강관 등의 부 식으로 인해 발생되었을 가능성이 더 높으며, 알 루미늄과 규소 등은 원수 속에도 포함된 것일 수 도 있으나 정수처리공정 중 혼화응집에 사용되 는 응집제 성분 또는 여과지로 누출된 원인일 가 능성이 존재한다. 다만 망간 등은 정수처리공정 에서 사용되는 성분이 아니므로, 원수에 포함된 망간이 정수처리공정에서 제거되지 못하고 관로 로 유입되어 결절 또는 슬라임 등과 함께 축적되 어 있는 것으로 보인다. 또한 철 성분은 슬라임 보다는 부식생성물인 결절 내부에 높은 비중을 차지하고 있고, 철 이외에 알루미늄, 망간, 그리 고 규소 등은 결절보다 슬라임에서 주요 성분으 로 나타났다.

Fig. 7에는 원수를 공급하는 unlined-CIP, 공업용수를 공급하는 unlined-DIP, 정수를 공 급하는 unlined-DIP와 SP 내부에 존재하는 결 절성분에 대한 $\mathrm{EDS}$ 분석결과이다. 결절 내 철 성분은 정수를 공급하는 $\mathrm{SP}$, unlined-DIP 순 으로 그 성분 비중이 높았고, 그 다음으로는 원 수를 공급하는 unlined-CIP, 공업용수를 공급 하는 unlined-DIP에서 철 성분 비중이 상대적 으로 낮게 나타났다. 그 외 알루미늄, 규소, 망 간 등은 반대로 공업용수를 공급하는 unlined$\mathrm{DIP}$ 가 상대적으로 그 비중이 높은 것으로 나타 났다.

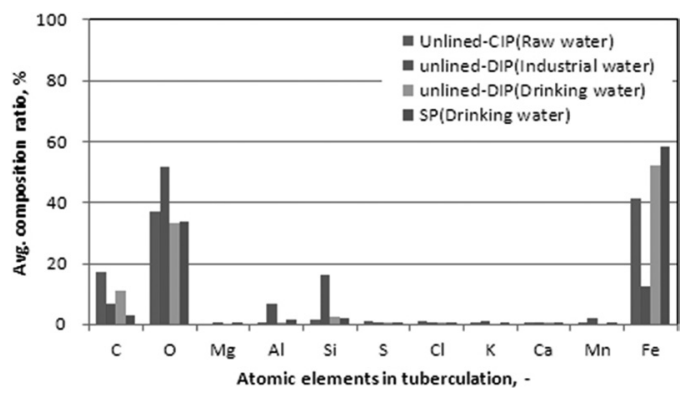

Fig. 7. Results of EDS analysis on tuberculation. 
Fig. 8에는 원수를 공급하는 concrete관, 공 업용수를 공급하는 $\mathrm{SP}$, 그리고 정수를 공급하는 $\mathrm{SP}$ 와 $\mathrm{CML}-\mathrm{DCIP}$ 내부에 존재하는 슬라임에 대 한 $\mathrm{EDS}$ 분석결과이다. Fig. 8에서 철 성분은 정 수를 공급하는 $\mathrm{CML}-\mathrm{DCIP}$ 내부에 존재하는 슬 라임에서 비중이 가장 높았고, 공업용수를 공급 하는 concrete관, $\mathrm{SP}$ 순이며, 정수를 공급하는 $\mathrm{SP}$ 가 가장 낮았다.

정수를 공급하는 $\mathrm{CML}-\mathrm{DCIP}$ 내부에 상대적 으로 철 성분 비중이 높게 나타난 이유는 내시 경 관측결과, 관 연결부 또는 각종 부속류 등이 부식이 심화되어 그 영향이 컸던 것으로 보여 진 다. 또한 원수를 공급하는 concrete관 내부에 존 재하는 슬라임에서도 철 성분 비중이 높게 나타 났다. 그 이유는 현재 concrete관이 매설된 구간 은 SP 또는 Unlined-DIP가 혼재되어 매설되어 있어 이들 금속관종으로부터 발생된 철 성분이 concrete관으로 이동, 축적되어 있기 때문으로 판단된다. 반면, 알루미늄 성분은 공업용수와 정 수를 공급하는 $\mathrm{SP}$ 에서 그 비중이 높았고 정수를 공급하는 $\mathrm{CML}-\mathrm{DCIP}$ 에서 가장 낮았다.

\subsection{ICP 분석결과}

Fig. 9에는 수집한 결절과 슬라임에 대한 대 표적인 6 개 무기원소 성분 $(\mathrm{Fe}, \mathrm{Cu}, \mathrm{Mn}, \mathrm{Zn}$, $\mathrm{Ca}, \mathrm{Al}$ 등)에 대한 ICP 분석결과를 나타내었다.

Fig. 9에서 보면, 결절 내 철 농도는 결절 $1 \mathrm{~kg}$ 당 $556.17 \mathrm{~g}$ 으로 가장 높았고, 그 다음으로 알

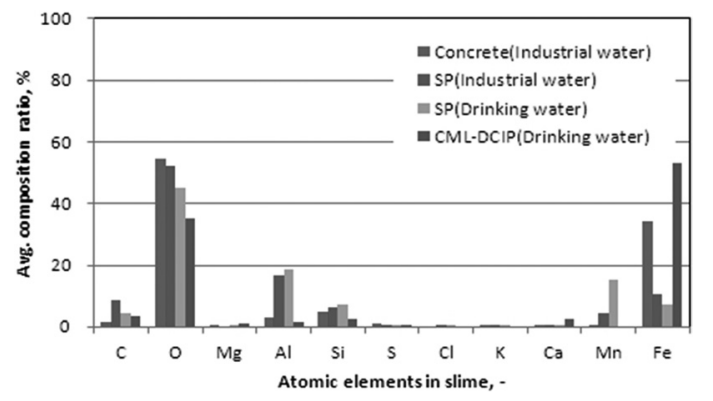

Fig. 8. Results of EDS analysis on slime.
루미늄이 $4.53 \mathrm{~g}, \mathrm{Cu}, \mathrm{Mn}, \mathrm{Zn}$, 그리고 $\mathrm{Ca}$ 등 은 $0.04 \sim 1.71 \mathrm{~g}$ 수준이었다. 이러한 결과는 Gerke et al. (2008)이 수행한 연구와 유사한 결 과를 보여주고 있다. Gerke et al.(2008)은 배 수관망의 무라이닝 주철관종에서 채취한 결절에 대한 ICP 분석에서 철이 $21 \sim 58 \%$, 알루미늄 이 $0.07 \sim 1.70 \%$, 황이 $0.55 \sim 4.16 \%$, 칼슘 이 $0.03 \sim 7.60 \%$, 망간이 $0.00 \sim 0.30 \%$ 등으 로 나타났고, 그 외 일부 납, 인, 구리, 니켈, 아 연 등이 미소한 양으로 포함되어 있는 것으로 보 고한 바 있다.

반면, 슬라임에서는 철 농도가 $1 \mathrm{~kg}$ 당 136.49 $\mathrm{g}$, 알루미늄이 $109.38 \mathrm{~g}$, 망간이 $54.39 \mathrm{~g}$, 칼 슘이 $6.63 \mathrm{~g}$, 구리와 아연이 각각 $0.33 \mathrm{~g}, 0.91$ $\mathrm{g}$ 으로 가장 낮았다. 따라서 슬라임에서는 무기 성분의 양보다는 유기물질 등의 함유량이 더 높 은 것으로 보인다. 이는 $\mathrm{VSS}$ 분석에서 슬라임의 $\mathrm{VSS}$ 가 결절에 비해 상대적으로 높았던 결과와 도 일치한다.

Fig. 10에는 원수를 공급하는 unlined-CIP, 공업용수를 공급하는 unlined-DIP, 그리고 정 수를 공급하는 unlined-DIP와 SP 내부에 존재 하는 결절성분의 $\mathrm{ICP}$ 분석결과이다. 원수를 공 급하는 unlined-CIP와 정수를 공급하는 $\mathrm{SP}$ 의 결절에서 철 농도는 각각 $616.91 \mathrm{~g} / \mathrm{kg}, 613.52$ $\mathrm{g} / \mathrm{kg}$ 으로 비슷한 수준이었으며, 그 다음으로 는 정수를 공급하는 unlined-DIP가 538.85 $\mathrm{g} / \mathrm{kg}$, 공업용수를 공급하는 unlined-DIP가

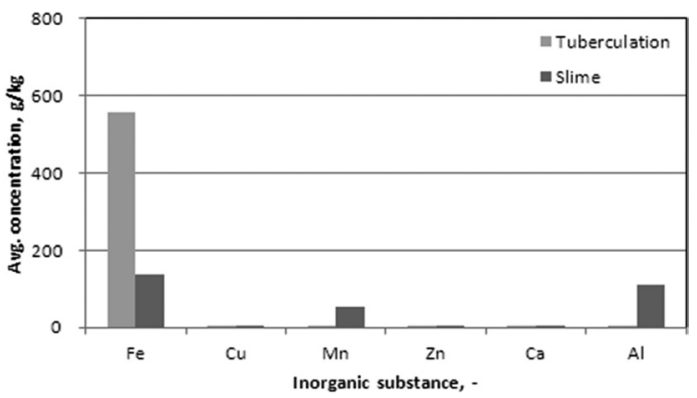

Fig. 9. Chemical composition comparison of inorganic substance on tuberculation and slime. 


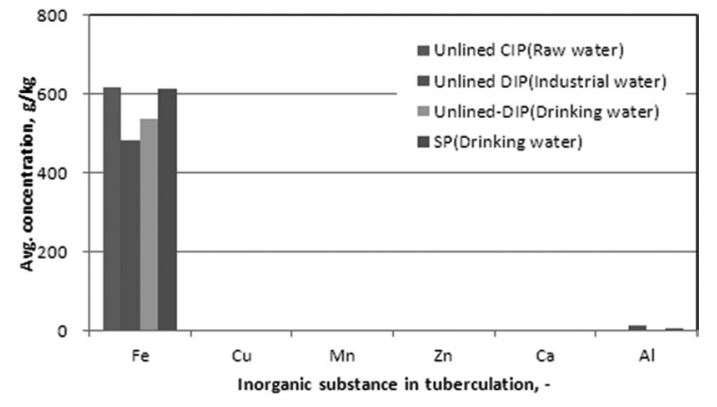

Fig. 10. Results of ICP analysis on tuberculation.

$483.96 \mathrm{~g} / \mathrm{kg}$ 으로 낮게 나타났다.

반면, 알루미늄은 공업용수를 공급하는 unlined-DIP에서 $12.47 \mathrm{~g} / \mathrm{kg}$ 으로 가장 높았고, 그 다음으로는 정수를 공급하는 $\mathrm{SP}$ 가 $4.01 \mathrm{~g} /$ $\mathrm{kg}$ 으로 분석되었다. 망간은 원수를 공급하는 unlined-CIP 결절에서 $3.75 \mathrm{~g} / \mathrm{kg}$ 으로 가장 높 았으며, 그 다음은 공업용수를 공급하는 unlined-DIP가 $2.70 \mathrm{~g} / \mathrm{kg}$, 정수를 공급하는 SP 가 $0.70 \mathrm{~g} / \mathrm{kg}$ 으로 가장 낮았다.

Fig. 11에는 공업용수를 공급하는 concrete 관과 $\mathrm{SP}$, 그리고 정수를 공급하는 $\mathrm{SP}$ 와 $\mathrm{CML}-$ $\mathrm{DCIP}$ 내부에 존재하는 슬라임에 대한 ICP 분석 결과이다. Fig. 11 에서 보면, 철 성분 농도는 정 수를 공급하는 CML-DCIP가 $410.77 \mathrm{~g} / \mathrm{kg}$ 으 로 가장 높았고, 그 다음으로는 공업용수를 공급 하는 concrete관이 $139.56 \mathrm{~g} / \mathrm{kg}$, SP가 100.60 $\mathrm{g} / \mathrm{kg}$ 이었으며, 정수를 공급하는 $\mathrm{SP}$ 의 철 성분 농도가 $56 \mathrm{~g} / \mathrm{kg}$ 으로 가장 낮았다.

반면, 알루미늄은 공업용수와 정수를 공급하 는 $\mathrm{SP}$ 의 슬라임에서 각각 $147.48 \mathrm{~g} / \mathrm{kg}, 137.15$ $\mathrm{g} / \mathrm{kg}$ 으로 가장 높았으며, 그 다음으로는 공업 용수를 공급하는 concrete관이 $63.14 \mathrm{~g} / \mathrm{kg}$ 이 었고, 정수를 공급하는 CML-DCIP 슬라임에서 $34.20 \mathrm{~g} / \mathrm{kg}$ 으로 가장 낮게 나타났다. 망간도 알루미늄과 비슷한 경향을 보였으며, 칼슘 성분 은 반대로 CML-DCIP에서 $16.11 \mathrm{~g} / \mathrm{kg}$ 으로 가 장 높았고, 그 다음으로는 concrete관, 그리고 정수와 공업용수를 공급하는 $\mathrm{SP}$ 순으로 분석되 었다.

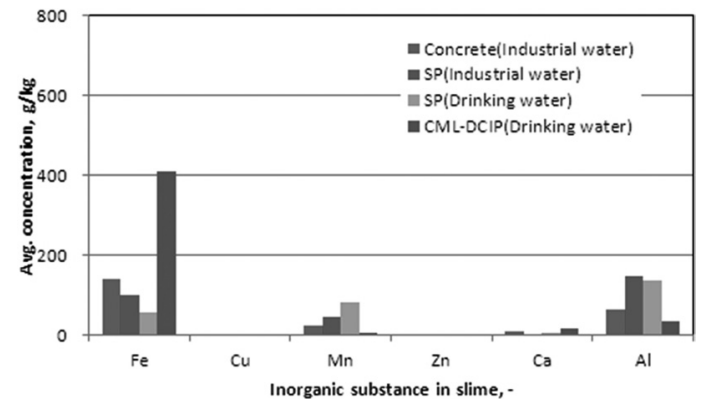

Fig. 11. Results of ICP analysis on slime.

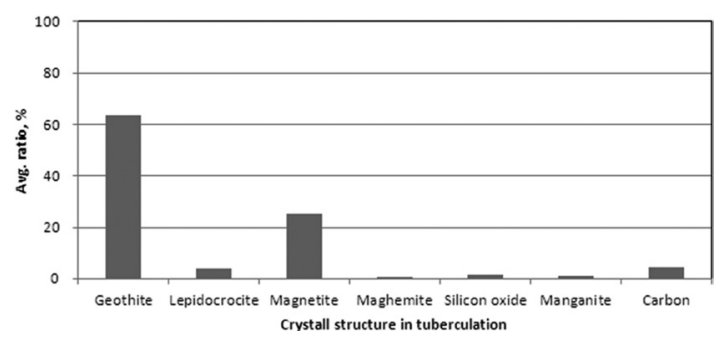

Fig. 12. Results of XRD analysis on tuberculation.

\section{$3.5 \mathrm{XRD}$ 분석결과}

Fig. 12 에는 국내에서 수집한 관체의 결절에 대 한 XRD를 이용하여 분석한 결정구조를 나타내었 다. Friedman et al. (2004)이 기존 문헌을 토대 로 조사한 결과를 보면, 가장 대표적으로 나타나 는 광물로 magnetite, geothite, lepidocrite, siderate, calcite 등 20 여종을 보고한바 있다. 반면, Fig. 12 에서 국내에서 수집한 관체의 결절 에서는 geothite $(\mathrm{FeO}(\mathrm{OH}))$, lepidocrocite $(\gamma-$ $\mathrm{FeO}(\mathrm{OH})$, magnetite $\left(\mathrm{Fe}_{3} \mathrm{O}_{4}\right)$, maghemite $\left(\mathrm{Fe}_{2} \mathrm{O}_{3}\right)$, silicon oxide( $\left.\mathrm{SiO}\right)$, manganite $(\mathrm{MnO}(\mathrm{OH}))$, carbon $(\mathrm{C})$ 등이 발견되었다. 이 중 geothite, lepidocrocite, magnetite, maghemite 등은 부식으로 발생되는 결정이며, 그 외 silicon oxide, manganite, carbon 등은 부 식생성물 보다는 관 내 유입된 망간 산화물 또는 모래여과지 또는 활성탄 흡착지로부터 유출될 수 있는 미세입자로 추정된다. Fig. 12에서 국 내에서 수집한 전체 부식생성물 중 가장 높은 비 율을 차지하고 있는 것은 geothite로 $63.4 \%$, 그 


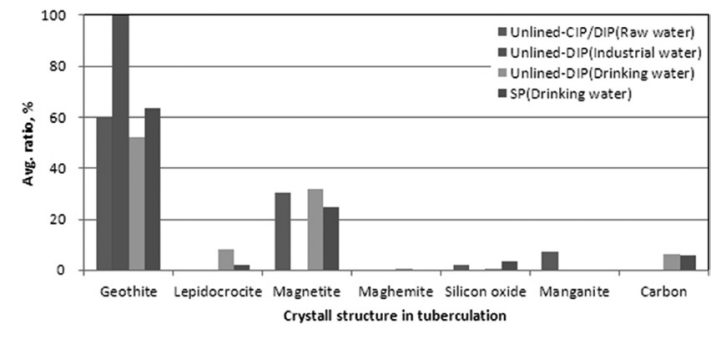

Fig. 13. Results of tuberculation XRD analysis on pipe material.

다음이 magnetite가 $25.2 \%$, lepidocrocite가 $4.1 \%$, maghemite가 $0.3 \%$ 순으로 나타났다.

Fig. 13에서 관종별/용도별로 보면, geothite 는 공업용수를 공급하는 unlined-DIP에서는 $100 \%$ 로 가장 높게 나타났으며, 그 외는 52.2 63.5\% 로 유사한 수준으로 보였다. lepidocrocite는 정수를 공급하는 unlined-DIP와 SP 에서만 각각 $8.1 \%, 2.2 \%$ 가 존재하는 것으로 나 타났으며, 다른 관종 또는 용도로 사용 중인 관 에서는 나타나지 않았다. maghemite는 unlined-DIP에서 일부 발견되었다.

Fig. 14에서 각 결절의 표면층(surface, 주로 붉은 색 표면), 중간충(middle, 주로 검은색), 그 리고 바닥층(bottom, 검은색)으로 구분해서 보 면, 바닥층 또는 표면보다 중간층에는 geothite 가 그리고 바닥층에는 magnetite가 더 높은 비 중을 차지하고 있는 것으로 보인다. 다만 Evans et al. (1937)은 부식침전물을 구성하는 서로 다 른 산화철이 계층구조를 이루고 있다고 언급한 바 있는 산화철은 주로 Magnetite $\left(\mathrm{Fe}_{3} \mathrm{O}_{4}\right)$ (자철 석, 산화철로 층상구조를 이루며, 검은 색을 띤 다), 그리고 Geothite $(\alpha-\mathrm{FeOOH})$ (침철석, 침 상 결정을 이루며 갈색, 적갈색을 띈다) 또는 Lepidocrocite $(\gamma-\mathrm{FeO}(\mathrm{OH}))$ (산화철 수화물로 오렌지 색을 띤다)를 포함하고 있다고 하였다. 그러나 본 연구에서 분석한 결과에 따르면, 비 록 결절 표면이 적색 또는 오렌지색을 띠고, 내 부는 검은색을 띤다고 해서 반드시 Magnetite, Geothite 또는 Lepidocrocite라고 판단하기는 다소 어려울 것으로 판단된다. 이는 표면 또는

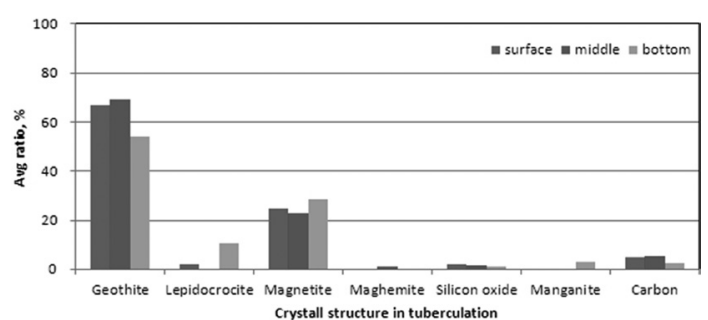

Fig. 14. Results of XRD analysis according to the location of tuberculation

중간 하부 층에 대부분 색깔의 구분 없이 $\mathrm{Mag}-$ netite, Geothite, 그리고 Lepidocrocite 등이 존재하는 것으로 나타났기 때문이다. Sarin 등 (2001)이 Boston에서 수집한 결절 분석에서도 그 위치에 관계없이 Geothite가 33.6 79.3\%, Magnetite는 $20.7 \sim 46.2 \%$, 그리고 Lepidocrocite가 $0.0 \sim 20.2 \%$ 로 보고한 바 있다.

\section{4. 결 론}

본 연구에서는 국내 상수관로 내 존재하는 다 양한 슬라임 등 축적물질과 부식으로 인해 관 내 부에 형성된 결절 등에 대한 물리화학적인 특성 을 분석하였고, 그 결과는 다음과 같다.

첫째, 관 내부에 존재하는 물질 중 휘발성부 유 고형물(VSS)이 차지하는 비율이 평균적으로 슬라임은 $24.18 \%$, 결절은 $12.03 \%$ 로 나타나 슬 라임 중 유기물 농도가 높은 것으로 나타났다. $\mathrm{VSS}$ 는 주로 미생물학적인 프로세스로 발생하는 것으로 보인다.

둘째, 슬라임과 결절에 대해 성분과 조성 등 을 관 용도별, 관종별로 조사한 결과, 관로 내부 에 존재하는 주요 성분으로는 철 부식생성물, 알 루미늄, 망간, 규소 등이며, 특히 결절 중에서 철이 차지하는 비율은 대부분 $60 \%$ 이상으로 나 타났다. 이중 철 부식생성물은 대부분 관 내 금 속관의 부식이 진행되면서 발생되므로 관 자체 에서 발생되는 특성이 있다. 슬라임 성분 중에 도 철 성분이 높게 나타나는데, 이는 플라스틱 관이라고 하더라도 그 이전의 금속성 관로와 관 
망시스템내 밸브, 펌프 등의 부속설비의 부식에 의한 영향으로 발생된 입자성의 철 등이 관로 내 부를 부유·이동하여 침전 및 축적되었을 가능 성이 높다. 따라서 비록 내식성 재질의 관종이라 하더라도 표면에 침전된 슬라임에는 적수 등을 유발할 가능성이 존재하는 철 부식 입자들도 존 재하고 있음을 파악할 수 있다. 알루미늄도 원수 속에 일부 존재하나, 정수처리공정의 혼화응집 공정에서 주로 알루미늄이 포함된 고분자응집제 를 주로 사용한다는 측면에서 혼화응집 후 여과 공정 등에서 제거되지 못하고, 관로 내로 유입되 어 후응집, 침전 등이 발생한 것으로 판단된다. 망간 등은 원수 속에 존재하며, 대부분 정수처리 공정에서 제거가 되나, 미량의 망간이온이 정수 처리공정이나 관로유하 중 산화되어 입자성 산 화망간으로 침전, 축적하게 된다.

셋째, 부식생성물을 제외한 활성탄 성분 일부 가 $\mathrm{XRD}$ 에서 관측되었는데, 활성탄 흡착지 또는 안트라사이트를 운영하는 시설로부터 미세한 입 자들이 관로내로 유입되어 침전 또는 기존 슬라 임과 결절에 포획되어 존재하는 것으로 보여 진 다. 모래 미세입자로 판단되는 $\mathrm{SiO}_{2}$ 입자들도 $\mathrm{EDS}, \mathrm{ICP}$ 또는 XRD 분석에서 관측되었는데, 이는 원수에서 발생하였으나 정수처리공정에서 미 제처리되었거나 혹은 모래여과공정에서 발생 되었을 가능성이 높은 것으로 판단된다.

넷째, XRD 분석결과, 부식생성물로 발생되 는 결정구조는 Geothite $>$ Magnetite $>$ Lepido crocite $>$ maghemite 순으로 나타났으며, 표면 에서 하부까지 다양하게 나타났다.

다섯째, 상수관로 내부에 존재하는 대표적인 입자성 물질, 활성탄 미세입자, 모래 미세입자, 철 부식생성물, 알루미늄, 망간 등을 저감하기 위해서는 이러한 물질의 발생원을 최대한 억제 하여 관로 내로의 유입을 방지(정수처리공정 개 선)해야 함은 물론이며, 이러한 물질을 효과적으 로 제거할 수 있는 플러싱을 포함한 다양한 관내 부 세척 기술의 적용(적정 유속 등) 이 필요할 것 으로 판단된다.

\section{References}

Allen, M. J., Taylor, R. H. \& Geldreich, E. E. 1980. The occurance of microorganisms in water main encrustations. J. Am. Wat. Wks. Assoc. 72, pp. 614-625.

Borch, T., Camper, A.k., Biederman, J.A., Butterfield, P.W., Gerlach, R., and Amonette, J.E.(2008), Evaluation of charcaterization techniques for iron pipe corrosion products and iron oxide thin films, Journal of environmental engineerring, October, $\mathrm{pp}$. 835 844.

Clark, R.M., Lykins, B.W., Block, J.C., Wymer, L.J. and Reasoner, D.J. (1994), Water quality changes in a simulated distribution system. Aqua 43, pp. 263.

Clement, J.A., Sandvig, A., Snoeyink, V., Kriven, W. \& Sarin, P. (1998). “Analyses and interpretation of the physical, chemical and biological characteristics of distribution system pipe scales". In Proc. AWWA WQTC, San Diego, Ca.

Emde, K.M.E.; Smith, D.W.; Facey, R.(1992.). Initial investigation of microbially influenced corrosion (MIC) in a low temperature water distribution system. WaterResearch, 26, pp. 169-175

Evans, U.R.(1937), Metallic corrosion, Passivity and Protection, London: Edward Arnold Ltd

Friedman M., Martel K., Hill A.(2004), Establishing Site-Specific Flushing Velocities, AWWARF

Gerke, T., Maynard, B., Schock, M.R., Lytle, D.L. (2008), Physiochemical characterization of five iron tuberckes from a single drinking water distribution system : Possible new insights on their formation and growth, Corrosion science 50, pp. 2030 2039.

Hallam, N.B., West, J.R., Forster, C.F. and Simms, J. (2001), The potential for biofilm growth in water distribution systems. Water Research 35(17), pp. 4063.

Kolle, W., \& Rosch, H.(1980), Untersuchungen an Rohrnetz-Inkrustierungen unter mineralogischen Gesichtspunkten. Vom Wasser 
55, pp. $159 \sim 178$

LeChevallier, M. W., T. M. Babcock, and R. G. Lee.(1987). Examination and characterization of distribution system biofilms. Appl. Environ. Microbiol. 53, pp. $2714-$ 2724.

Nagy L. A., Olson B. H.(1985) Occurrence and significance of bacteria, fungi, and yeasts associated with distribution pipe surfaces. Proceedings of the American Water Works Association, Water Quality Technical Conference. (American Water Works Association, Denver, Colo), p 213.

Sarin, P., Snoeyink, V.L., Bebee, J., Kriven, W.M. and Clement, J.A.(2001), Physicochemical characteristics of corrosion scales in old iron pipes, Wat. Res. Vol. 35, No. 12, pp. $2961-2969$.

Smith, S. E., Colbourne, J. S., Holt, D. M., Lloyd, B., and Bisset, A., (1997). "An Examination of Nature and Occurrence of Deposits in Distribution System and Their Effect on Water Quality", Proceeding of Water Quality Technology Conference, Denver, Colo, AWWA

Vreeburg, J.H.G. (2007); "Discolouration in drinking water systems: a particular approach", Civil Engineering, TU Delft, PhD Thesis, ISBN: 978-90-74741-91-0

Walski, T.M. (1991). "Understanding Solids Transport in Water Distribution Systems". Water Quality Modelling In Distribution Systems, USA, pp 305-309. 